\title{
Erratum to: Confined Klein-Gordon oscillator from a (2+1)-dimensional Gürses to a Gürses or a pseudo-Gürses space-time backgrounds: Invariance and isospectrality
}

\author{
Omar Mustafa ${ }^{\mathrm{a}}$ iD \\ Department of Physics, Eastern Mediterranean University, G. Magusa, North Cyprus, Mersin 10, Turkey
}

Published online: 14 February 2022

(C) The Author(s) 2022

Erratum to: Eur. Phys. J. C (2022) 82:82 https://doi.org/ 10.1140/epjc/s10052-022-10043-3

In the original article the following typesetting mistakes were corrected:

1. In the first line of the abstract "Klein-shGordon" should be "Klein-Gordon".

2. "ccc" should be removed from the metric tensors in equations (4), (29), (30), (42), and (43).

The original article has been corrected. The publisher apologizes for the inconvenience caused.
Open Access This article is licensed under a Creative Commons Attribution 4.0 International License, which permits use, sharing, adaptation, distribution and reproduction in any medium or format, as long as you give appropriate credit to the original author(s) and the source, provide a link to the Creative Commons licence, and indicate if changes were made. The images or other third party material in this article are included in the article's Creative Commons licence, unless indicated otherwise in a credit line to the material. If material is not included in the article's Creative Commons licence and your intended use is not permitted by statutory regulation or exceeds the permitted use, you will need to obtain permission directly from the copyright holder. To view a copy of this licence, visit http://creativecomm ons.org/licenses/by/4.0/.

Funded by $\mathrm{SCOAP}^{3}$.

The original article can be found online at https://doi.org/10.1140/ epjc/s10052-022-10043-3.

a e-mail: omar.mustafa@emu.edu.tr (corresponding author) 